\title{
Comparison between modified DNA extraction protocols and commercial isolation kits in grapevine (Vitis vinifera L.)
}

\author{
M. Akkurt \\ Department of Horticulture, Faculty of Agriculture, Ankara University, \\ Ankara, Turkey \\ Corresponding author: M. Akkurt \\ E-mail: akkurt@agri.ankara.edu.tr
}

Genet. Mol. Res. 11 (3): 2343-2351 (2012)

Received April 10, 2012

Accepted June 13, 2012

Published August 13, 2012

DOI http://dx.doi.org/10.4238/2012.August.13.8

\begin{abstract}
Various protocols have been developed and used for DNA extraction in grapevine. However, owing to the long duration of the isolation steps in previously developed protocols, researchers have preferred to use isolation kits for studies in recent years. In our study, the DNA yield and purity obtained using six methods - namely three DNA isolation protocols and three commercial DNA isolation kits - were compared. Modifications were made and the isolation steps were shortened in the previously developed DNA isolation protocols to achieve more rapid and practical protocols. The samples were taken from plants grown under vineyard and greenhouse conditions in two periods during spring and autumn. The best results among the six DNA isolation methods were discussed. The results were also supported with polymerase chain reaction analyses conducted with isolated DNAs.
\end{abstract}

Key words: Grapevine; DNA extraction; DNA isolation kits 


\section{INTRODUCTION}

Grapevine (Vitis vinifera L.) is among the most economically important fruit crops and one of the species commonly used in biotechnological studies. Molecular techniques in grapevine are widely used for a variety of purposes such as breeding studies, determination of gene sources, identification of origins, parent assignation, pedigree analysis, genome mapping, and marker-assisted selection. The most important starting point of these studies is the extraction of genomic DNA at the desired yield and purity.

DNA extraction from plant tissues, unlike that from mammalian tissues, is more difficult owing to the existence of the tough cell wall that surrounds plant cells (Manen et al., 2005). Because of this characteristic, as well as specific pigments and different secondary metabolites, DNA extraction from plant tissues requires particular care and skill during isolation (Varma et al., 2007). For this reason, various DNA extraction protocols have been developed in numerous biotechnological research laboratories using plant tissues (Murray and Thompson, 1980; Doyle and Doyle, 1987; Thomas et al., 1993; Lodhi et al., 1994; Lefort et al., 1998). The main purpose of these protocols is to obtain DNA extraction at high yield and purity. However, owing to the existence of multiple isolation steps in these protocols, achieving results can be time consuming. Therefore, in recent years, more rapid and practical DNA isolation methods have become important. Studies exploring more rapid DNA extraction with lower chemical use through modification of various DNA isolation protocols have increased (Khan et al., 2004; Alaey et al., 2005; Manen et al., 2005).

Additionally, kits developed by several manufacturers (Promega Corporation, Madison, WI, USA; Qiagen GmbH, Hilden, Germany; Norgen Biotek Corporation, Thorold, ON, Canada; Epicentre Biotechnologies, Madison, WI, USA; Mo Bio Laboratories, West Carlsbad, CA) for DNA isolation from animal and plant tissues have gained preference among researchers. Commercial DNA isolation kits have the significant advantages of limited and smaller amounts of chemical use, shortened isolation steps, and more rapid achievement of results. However, these kits have noteworthy disadvantages such as high costs, non-repeatability of the DNA yield and purity levels declared by the manufacturer, and isn't successful enough for use of DNA in biotechnological studies.

In this study, three frequently used DNA isolation protocols (Thomas et al., 1993; Lodhi et al., 1994; Lefort et al., 1998) were compared with three commercial isolation kits to explore the most efficient DNA isolation method for grapevine. The number of leaf samples, amount of chemicals, and duration of isolation steps were modified in traditional isolation protocols to achieve more rapid and more practical methods.

\section{MATERIAL AND METHODS}

\section{Plant material}

Leaf samples taken in two periods of spring and autumn from "Muscat of Hamburg", "Alphonse Lavalleé", and "Sultani" cultivars grown in vineyards as well as "Alphonse Lavalleé" x "Sultani" and "Muscat of Hamburg" x "Sultani" $F_{1}$ hybrids grown under greenhouse conditions were used in the study. The leaf samples were immediately transferred to the molecular biology laboratory at Ankara University. 
Fresh plant material was ground in liquid nitrogen using a sterile mortar and pestle to give a green powder. The powder was transferred to new $1.5-\mathrm{mL}$ polypropylene tubes using a spatula and stored at $-80^{\circ} \mathrm{C}$.

\section{Isolation methods}

The DNA isolation protocols of Thomas et al. (1993), Lodhi et al. (1994), Lefort et al. (1998) and 3 commercial DNA isolation kits were used in the study. In all protocols, 50 $\mathrm{mg}$ leaf samples was used, and the amounts of chemicals used and durations of isolation steps were modified as follows:

\section{Thomas et al. (1993)}

A 50-mg leaf sample was thawed and suspended in $500 \mu \mathrm{L}$ buffer A [50 mM ethylenediaminetetraacetic acid (EDTA), $200 \mathrm{mM}$ Tris-HCl, $\mathrm{pH} 8.0,0.25 \mathrm{M} \mathrm{NaCl}, 0.1 \%$ (v/v) 2-mercaptoethanol, $2.5 \%(\mathrm{w} / \mathrm{v})$ polyvinylpyrrolidone (molecular mass $40 \mathrm{kDa})]$. The solution was centrifuged at $4000 \mathrm{rpm}$ for $5 \mathrm{~min}$ at $4^{\circ} \mathrm{C}$. The pellet was resuspended in $100 \mu \mathrm{L}$ buffer B [50 mM EDTA, $200 \mathrm{mM}$ Tris-HCl, pH 8.0, $0.5 \mathrm{M} \mathrm{NaCl}, 1 \%$ (v/v) 2-mercapto-ethanol, 2.5\% (w/v) polyvinylpyrrolidone, $3 \%$ sarkosyl, $20 \%$ ethanol] and incubated at $37^{\circ} \mathrm{C}$ for $15 \mathrm{~min}$ with shaking. An equal volume of chloroform/isoamyl alcohol was added, and the mixture was vigorously vortexed and centrifuged at $11,500 \mathrm{rpm}$ for $5 \mathrm{~min}$ to enact phase separation. The supernatant was carefully removed to a new tube, and a 0.54 volume of isopropanol was added. After incubation for $5 \mathrm{~min}$ on ice, the solution was centrifuged at 14,000 rpm for 1 min. The DNA pellet was dissolved in $50 \mu \mathrm{L}$ TE $(10 \mathrm{mM}$ Tris- $\mathrm{HCl}$ and $1 \mathrm{mM}$ EDTA, pH 8.0), combined with $3 \mu \mathrm{L}$ RNase enzyme, and incubated at $37^{\circ} \mathrm{C}$ for $15-20 \mathrm{~min}$. A 1:2 volume of 7.5 $\mathrm{M}$ ammonium acetate was added to remove proteins, and the mixture was centrifuged at 5000 rpm for $5 \mathrm{~min}$. The supernatant was removed to new tubes and combined with a 1:2 volume of isopropanol. After centrifugation at $5000 \mathrm{rpm}$ for $1 \mathrm{~min}$, the solution was kept at room temperature for $10 \mathrm{~min}$ to remove isopropanol. DNA was resuspended in $50 \mu \mathrm{L} \mathrm{TE}$.

\section{Lodhi et al. (1994)}

Five milligrams of polyvinylpolypyrrolidone (P6755; Sigma-Germany) and $600 \mu \mathrm{L}$ extraction buffer (100 mM Tris- $\mathrm{HCl}$, pH 8.0, $20 \mathrm{mM}$ EDTA, $1.4 \mathrm{M} \mathrm{NaCl}, 2 \%$ cetyltrimethylammonium bromide, $0.1 \% \mathrm{v} / \mathrm{v} 2$-mercapto-ethanol) were added to a 50-mg leaf sample, and the solution was incubated at $60^{\circ} \mathrm{C}$ for $15 \mathrm{~min}$. Then $600 \mu \mathrm{L}$ chloroform:isoamyl alcohol (24:1) was added to the solution and it was centrifuged at $6000 \mathrm{rpm}$ for $5 \mathrm{~min}$. The supernatant was carefully transferred into new polypropylene tubes and combined with a 1:2 volume of $5 \mathrm{M} \mathrm{NaCl}$ and 2 volumes of $95 \%$ ice-cold ethanol. The tubes were shaken carefully, kept at $4^{\circ} \mathrm{C}$ for $20 \mathrm{~min}$ for collection of DNA fibrils, and then centrifuged at $6000 \mathrm{rpm}$ for $3 \mathrm{~min}$. The supernatant was carefully removed and the DNA pellet was combined with $700 \mu \mathrm{L} 70 \%$ ethanol and centrifuged at $6000 \mathrm{rpm}$ for $3 \mathrm{~min}$ at room temperature. The supernatant was carefully removed and the pellet kept at room temperature for 10-15 min for ethanol precipitation of DNA. After complete removal of ethanol, the DNA was dissolved in $50 \mu \mathrm{L}$ TE, $2 \mu \mathrm{L}$ RNAase was added, and kept at $37^{\circ} \mathrm{C}$ for $30 \mathrm{~min}$ to remove RNA. 


\section{Lefort et al. (1998)}

Five hundred microliters of DNA extraction buffer [50 mM Tris-HCl, $\mathrm{pH} 8.0,20 \mathrm{mM}$ EDTA, $0.7 \mathrm{M} \mathrm{NaCl}, 0.4 \mathrm{M} \mathrm{LiCl}, 1 \%$ (w/v) cetyltrimethylammonium bromide, $1 \%$ (w/v) polyvinylpolypyrrolidone $40,2 \%(\mathrm{w} / \mathrm{v})$ sodium dodecyl sulfate], and $5 \mu \mathrm{L} \beta$-mercaptoethanol were added to a 50-mg leaf sample, mixed, and incubated for $10 \mathrm{~min}$ at $65^{\circ} \mathrm{C}$ in a water bath. After incubation, $250 \mu \mathrm{L}$ chloroform/isoamyl alcohol $(24: 1)$ was added to the tube and centrifuged at 14,000 rpm for $3 \mathrm{~min}$. The supernatant was carefully transferred into a new polypropylene tube and centrifuged for $1 \mathrm{~min}$ at $14,000 \mathrm{rpm}$. The supernatant $(0.5 \mathrm{~mL})$ was transferred to a new tube to which $0.5 \mathrm{~mL}$ ice-cold isopropanol was added, and the mixture was centrifuged for $1 \mathrm{~min}$ at 14,000 rpm. The DNA pellet was washed with $0.7 \mathrm{~mL} 70 \%$ ethanol and centrifuged for $1 \mathrm{~min}$ at $14,000 \mathrm{rpm}$. The supernatant was withdrawn, and the pellets were kept at room temperature for $10 \mathrm{~min}$. The pellets were resuspended in $50 \mu \mathrm{L}$ TE. To remove RNA, 2 $\mu \mathrm{L}$ RNAase was added and kept at $37^{\circ} \mathrm{C}$ for $30 \mathrm{~min}$.

\section{Commercial isolation kits}

The DNA isolation steps of the three commercial isolation kits used in the study were implemented following manufacturer protocols. In all of these protocols, a 50-mg leaf sample was used. The basic features of the kits as declared by their manufacturers are listed in Table 1.

Table 1. Basic features of the isolation kits used in the study.
\begin{tabular}{lllcc}
\hline Kit & Plant tissue & Purification based & Amount of starting material (mg) & DNA yield (ng) \\
\hline 1 & Grapevine leaf & Nonenzymatic approach & 50 & 500 \\
2 & Tomato leaf & Salt precipitation & 50 & $7000-12,000$ \\
3 & Grapevine leaf & Spin column chromatography & 50 & 10,000 \\
\hline
\end{tabular}

\section{Polymerase chain reaction (PCR) amplification}

The DNAs extracted using the isolation methods were amplified using simple sequence repeat primers VMC7f2 and VMC4f3.1 by PCR.

PCRs were performed in a total volume of $20 \mu \mathrm{L}$ containing $0.25 \mathrm{mM}$ deoxyribonucleotide triphosphates, $0.25 \mu \mathrm{M}$ of each primer, $0.5 \mathrm{U}$ Taq DNA polymerase, $1.5 \mathrm{mM}$ $\mathrm{MgCl}_{2}$, and $20 \mathrm{ng}$ template DNA in 1X PCR buffer (10 mM Tris-HCl, $50 \mathrm{mM} \mathrm{KCl}, \mathrm{pH} \mathrm{8.3).}$ Temperature profiles were run in Biometra T-1 Thermoblock (Biometra, Göttingen, Germany) and consisted of an initial denaturation step at $95^{\circ} \mathrm{C}$ for 3 min followed by 30 cycles of denaturation at $95^{\circ} \mathrm{C}$ for $1 \mathrm{~min}$, annealing for $1 \mathrm{~min}$, and a synthesis step at $72^{\circ} \mathrm{C}$ for 2 min. The final extension took place at $72^{\circ} \mathrm{C}$ for $10 \mathrm{~min}$.

\section{Visualization, DNA quantification, and purity measurement}

The quality of the DNA bands was determined using electrophoresis on $1 \%$ agarose gel. Each sample contained $4 \mu \mathrm{L}$ extracted DNA and $6 \mu \mathrm{L}$ loading buffer. PCR products $(7 \mu \mathrm{L})$ were visualized using electrophoresis on $1.5 \%$ agarose gel. Electrophoresis was carried out under a steady voltage of 100 for 1-1.5 h and visualized under ultraviolet light, and the results were documented using a Bio Imaging System (Syngene, Cambridge, UK). 
The yield and purity of the extracted DNAs were measured spectrophotometrically using a Nanodrop spectrophotometer (ND-1000 UV/Vis-USA). The measurements were repeated three times for DNA yields in $\mathrm{ng} / \mu \mathrm{L}$, and purity was assessed at a 260/280 nm absorbance ratio and the averages of the measurements were taken.

\section{Statistical analysis}

The differences between DNA isolation protocols according to extracted DNA yield were tested with one-way analysis of variance. The Tukey multiple comparison test was used to determine the variation between means at a 5\% significance level. Tukey test results were explained with letters as means \pm standard error values. Differences between protocols were determined using the $t$-test. P values of the $t$-test results were interpreted and given as a letter next to the mean values. Variance analyses and $t$-tests were carried out using the Minitab 16 package, and Tukey tests were performed using Mstat-C.

\section{RESULTS AND DISCUSSION}

In this study, traditional isolation protocols were modified and compared with commercial DNA isolation kits for DNA quantity and purity. DNA was prepared using three DNA extraction protocols and kits and tested on agarose gel and with a spectrophotometer for DNA yield and quality (Table 2).

In the DNA isolation protocols, the amounts of leaf sample were decreased from 100 to $50 \mathrm{mg}(1: 2)$ in the protocol of Lefort et al. (1998), from 500 to $50 \mathrm{mg}(1: 10)$ in the protocol of Lodhi et al. (1994), and from 2000 to $50 \mathrm{mg}$ (1:40) in the protocol of Thomas et al. (1993). The amounts of chemicals and solutions were also decreased and the duration of the isolation steps shortened to obtain a more rapid and practical isolation that saved time and labor. The protocols of the commercial kits were implemented according to manufacturer protocols, but equal amounts of leaf sample-i.e.; $50 \mathrm{mg}$-were used with each kit.

DNA bands produced using the traditional methods were brighter and more distinct compared with those obtained using the isolation kits despite the use of equal amounts of samples in the latter. DNA yield and purity were determined spectrophotometrically using a Nanodrop ND-1000 spectrophotometer. The results of the statistical analyses of the differences between isolation protocols are shown in Table 2. Variance analysis showed that the difference between protocols was statistically significant $(\mathrm{P}<0.01)$. Therefore, the difference was determined using the Tukey test (see Table 2, letters). The average values that lack a common letter were significant $(\mathrm{P}<0.01)$.

As shown in Table 2 , the highest DNA yield $(1811.3 \mathrm{ng} / \mu \mathrm{L})$ was extracted from the spring sample of the "Alphonse Lavalleé" cultivar using the protocol of Lefort et al. (1998), followed by that extracted from the spring samples of "Muscat of Hamburg" $x$ "Sultani" $F_{1}$ hybrids (1586.4 ng/ $\mu \mathrm{L}$ ) and the spring samples of "Alphonse Lavalleé" $\mathrm{x}$ "Sultani" $\mathrm{F}_{1}$ hybrids (1434.6 $\mathrm{ng} / \mu \mathrm{L}$ ) using the protocol of Lodhi et al. (1994). The results revealed that the lowest DNA yields (29.5 ng/ $\mu \mathrm{L}$ "Muscat of Hamburg x Sultani" autumn samples) were obtained using the protocol of Thomas et al. (1993). These yields remained remarkably below the values reported by the authors (25-150 $\mu \mathrm{g}$ DNA g/fresh weight). This difference may be attributable to the sample amount used for isolation, which was one-fortieth the amount used in the original protocol. The extra protein precipitation step in this method may have also caused a loss of DNA. 


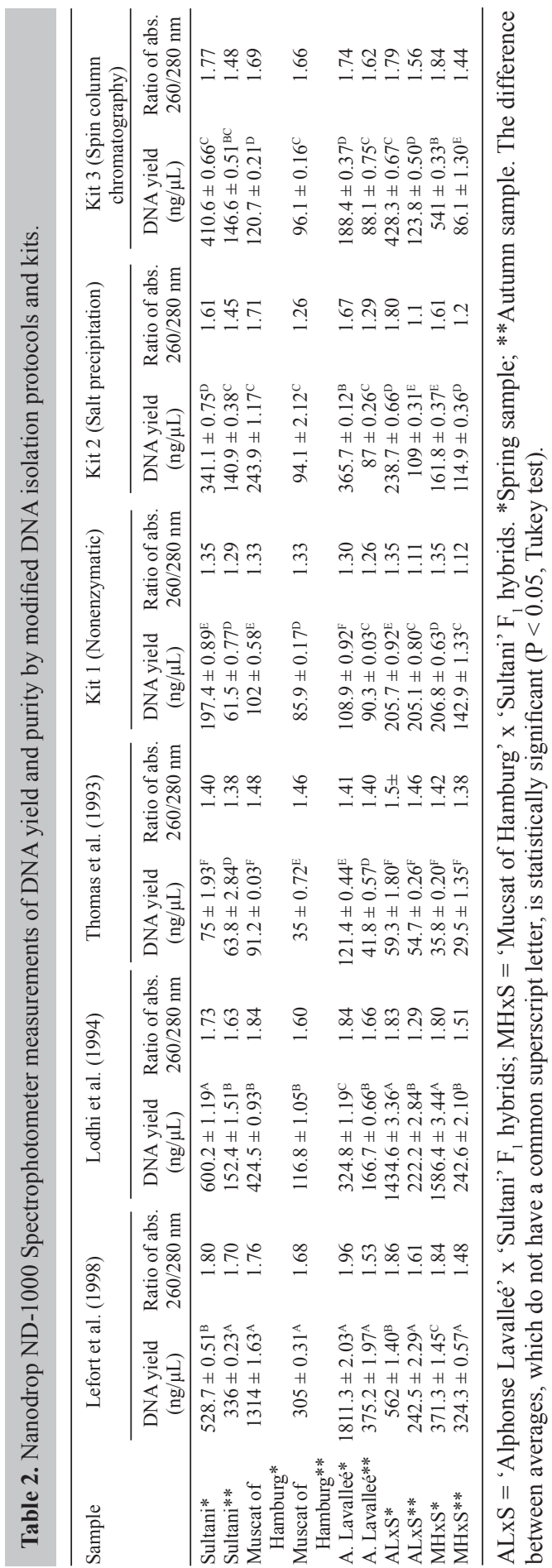


The highest DNA yield obtained using the commercial kits (541 ng/ $\mu \mathrm{L}$, "Muscat of Hamburg x Sultani" spring sample) was obtained from kit 3 (spin column chromotograph). Generally, the DNA yields obtained with the isolation kits were significantly lower than those obtained with the other isolation protocols (expect those using the protocol of Thomas et al. (1993)).

Comparison between cultivars grown in vineyards and $\mathrm{F}_{1}$ hybrids grown under greenhouse conditions revealed that the highest DNA yield obtained using the protocol of Lefort et al. (1998) was extracted from the "Alphonse Lavalleé" cultivar grown under vineyard conditions, whereas the highest DNA yields obtained using the protocol of Lodhi et al. (1994) were extracted from the "Alphonse Lavalleé x Sultani" and "Muscat of Hamburg x Sultani" $F_{1}$ hybrids. No significant differences in DNA yield were recorded between the source materials when the commercial isolation kits were used.

In addition to DNA yield, DNA purity is a significant determinant of the effectiveness of DNA isolation methods. The ratio of absorbance at $260 / 280 \mathrm{~nm}$ is 1.8 for a pure DNA sample, and a decrease in that ratio indicates contamination by proteins, whereas the presence of RNA increases the ratio (Varma et al., 2007). Generally a ratio between 1.8 and 2.0 indicates uncontaminated DNA (Sambrook and Russell, 2001; Alaey et al., 2005).

When the DNA purity obtained using the protocols was compared, the protocols of Lefort et al. (1998) and Lodhi et al. (1994) were most successful. The DNA purity in spring samples ranged from 1.76 to 1.96 with the protocol of Lefort et al. (1998) and from 1.73 and 1.84 with the protocol of Lodhi et al. (1994). Among the commercial isolation kits, the highest DNA purity in spring samples was obtained from kit 3 (1.69-1.84), whereas the lowest DNA purity was obtained from kit 1 (1.30-1.35).

DNA yield and purity in autumn samples was remarkably lower than those in spring samples using all methods. This difference is attributable to the more frequent cell division and lower deposition of polysaccharides and secondary metabolites in young leaves (Peterson et al., 1997; Alaey et al., 2005). The best results in autumn samples for both DNA yield (242.5$375.2 \mathrm{ng} / \mu \mathrm{L})$ and purity (1.48-1.70) were obtained using the protocol of Lefort et al. (1998), followed by the DNA yield of 116.8-242.6 ng/ $\mu \mathrm{L}$ using the protocol of Lodhi et al. (1994) and DNA purity of 1.44-1.66 using kit 3. DNA purities ranged between 1.11 and 1.33 and between 1.1 and 1.45 with kits 1 and 2 , respectively.

The most important and crucial determinant of DNA quality is its repeatability and usefulness in molecular genetic studies. Therefore, the quality and quantity of extracted DNA was tested using PCR with the two simple sequence repeat primers VMC7f2 and VMC4f3.1. Twenty nanograms per microliter DNA was used in PCR analyses, as previously optimized for these primers. With the VMC7f2 primer, the highest amplification ratio of $100 \%$ was obtained with the protocol of Lodhi et al. (1994), followed by the protocol of Lefort et al. (1998) and Thomas et al. (1993) with 90\% amplification ratios. The commercial isolation kits produced results that were lower than those produced by the traditional methods. No amplification occurred using kit 1 with the DNAs extracted from either spring or autumn samples. Amplification ratios obtained from kits 2 and 3 were 50 and 70\%, respectively (Figure 1). The VMC4f3.1 primer produced results to similar to those of VMC7f2. In PCR analyses, whereas traditional methods yielded amplification ratios of 70-100\% (protocols of Thomas et al. (1993) and Lefort et al. (1998)), the commercial isolation kits yielded amplification ratios of 30-60\% (kits 1 and 3). 
A

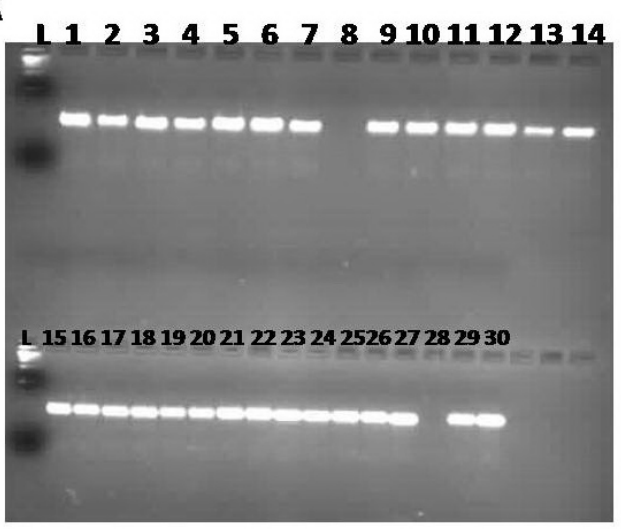

B

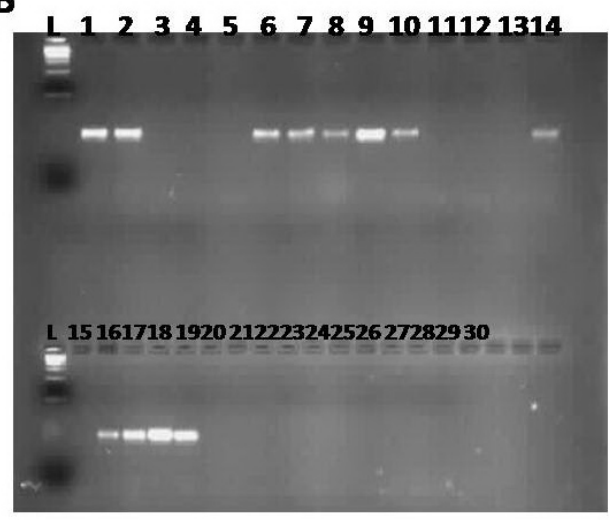

Figure 1. Display of PCR amplification results with VMC7f2 SSR primer. A. Lanes 1, 3, 5, 7, 9 = Lefort et al. (1998) spring samples; lanes 2, 4, 6, 8, 10= Lefort et al. (1998) autumn samples; lanes 11, 13, 15, 17, 19= Lodhi et al. (1994) spring samples; lanes 12,14, 16, 18, 20 = Lodhi et al. (1994) autumn samples; lanes 21, 23, 25, 27, $29=$ Thomas et al. (1993) spring samples; lanes 22, 24, 26, 28, 30 = Thomas et al. (1993) autumn samples. B. Lanes 1, $3,5,7,9=$ kit 3 spring samples; lanes 2, 4, 6, 8, 10= kit 3 autumn samples; lanes 11, 13, 15, 17, 19= kit 2 spring samples; lanes 12,14,16,18,20= kit 2 autumn samples; lanes 21,23, 25, 27, $29=$ kit 1 spring samples; lanes 22, $24,26,28,30=$ kit 1 autumn samples.

The aim of DNA isolation protocols is to obtain pure DNA in high yield with a rapid and practical extraction. Using most traditional DNA extraction methods, approximately 28 samples/day can be isolated by a researcher (Khan et al., 2004). This slow rate leads to significant requirements of time and labor in molecular genetic studies. Therefore, in recent years, more practical and rapid DNA isolation methods have been developed (Lo Piccolo et al., 2010; Carrier et al., 2011).

The findings of our study indicate that modifications of these traditional methods significantly shorten their duration. Isolations for 16 samples were completed in approximately $60 \mathrm{~min}$ using all three protocols. With commercial kits, we completed the isolations in $60 \mathrm{~min}$ using kit 1, in 90 min using kit 2, and in 60 min using kit 3.

Although the duration of isolation was similar for commercial kits and traditional methods, the DNA yield and purity were higher with traditional methods (especially using the protocols of Lefort et al. (1998) and Lodhi et al. (1994)). The modified traditional methods also produced better results in PCR analyses of the extracted samples compared to those obtained with commercial kits.

Commercial DNA isolation kits have been widely preferred in recent years owing to their significant advantages of practical methodology and rapid results. They have disadvantages of high cost and non-repeatability of the DNA yield and purity declared by the manufacturers. Three modified DNA isolation protocols and three commercial kits were compared in this study. With slight modifications, the traditional protocols proved to be more practical, easier, and faster than the protocols of the kits. The protocols of Lefort et al. (1998) and Lodhi et al. (1994) proved particularly successful and are recommended for DNA isolation in grapevine molecular genetic studies. 


\section{ACKNOWLEDGMENTS}

The author thanks Kamil Karataş for assistance with laboratory work.

\section{REFERENCES}

Alaey M, Naderi R, Vezvaei A, Khalighi A, et al. (2005). Comparing study between four different methods of genomic DNA extraction from Cyclamen persicum Mill. Int. J. Agric. Biol. 7: 882-884.

Carrier G, Santoni S, Rodier-Goud M, Canaguier A, et al. (2011). An efficient and rapid protocol for plant nuclear DNA preparation suitable for next generation sequencing methods. Am. J. Bot. 98: e13-e15.

Doyle JJ and Doyle JL (1987). A rapid DNA isolation procedure for small quantities of fresh leaf tissue. Phytochem. Bull. 19: 11-15.

Khan IA, Awan FS, Ahmad A and Khan AA (2004). A modified mini-prep method for economical and rapid extraction of genomic DNA in plants. Plant Mol. Biol. Rep. 22: 89a-89e.

Lefort F, Lally M, Thompson D and Douglas GC (1998). Morphological traits, microsatellite fingerprinting and genetic relatedness of a stand of elite oaks $(Q$. robur L.) at Tullynally, Ireland. Silvae Genet. 47: 5-6.

Lo Piccolo S, Conigliaro G, Francesca N, Settanni L, et al. (2010). An optimized and rapid DNA extraction method from leaves of grapevine suitable for PCR-DGGE based analysis. J. Biotechnol. 150: 486.

Lodhi MA, Ye GN, Weeden NF and Reisch BI (1994). A simple and efficient method for DNA extraction from grapevine cultrivars and Vitis species. Plant Mol. Biol. Rep. 12: 6-13.

Manen JF, Sinitsyna O, Aeschbach L and Marlov AV (2005). A fully automatable enzymatic method for DNA extraction from plant tissues. BMC Plant Biol. Rep. 5: 23.

Murray MG and Thompson WF (1980). Rapid isolation of high molecular weight plant DNA. Nucleic Acids Res. 8: 43214325.

Peterson DG, Boehm KS and Stack SM (1997). Isolation of milligram quantities of nuclear DNA from tomato (Lycopersicon esculentum), a plant containing high levels of polyphenolic compounds. Plant Mol. Biol. Rep. 15: 148-153.

Sambrook J and Russell DW (2001). Molecular Cloning. Vol. 1. Cold Spring Harbor Laboratory Press, Cold Spring Harbor.

Thomas MR, Matsumoto S, Cain P and Scott NS (1993). Repetitive DNA of grapevine: classes present and sequences suitable for cultivar identification. Theor. Appl. Genet. 86: 173-180.

Varma A, Padh H and Shrivastava N (2007). Plant genomic DNA isolation: An art or a science. Biotechnol. J. 2: 386-392. 